\begin{tabular}{cc|c}
\hline Tar. Bil. Der. & Journal of Agricultural Sciences \\
& $\begin{array}{c}\text { Dergi web sayfası: } \\
\text { www.agri.ankara.edu.tr/dergi }\end{array}$ & Journal homepage: \\
& www.agri.ankara.edu.tr/journal
\end{tabular}

\title{
Consumers' Purchase Intention toward Safety Labeled Dairy Products in the Black Sea Region of Turkey
}

\author{
Mehmet BOZOGLU ${ }^{a}$, Chung L. HUANG ${ }^{\text {b }}$, Wojciech J. FLORKOWSKI ${ }^{\mathrm{c}}$, Bakiye KILIC TOPUZ \\ a Ondokuz Mayls University, Department of Agricultural Economics, 55139, Samsun, TURKEY \\ ${ }^{b}$ Athens, GA 30602, USA \\ ${ }^{c}$ University of Georgia, Agricultural and Applied Economics, Athens GA 30602, USA.
}

\section{ARTICLE INFO}

Research Article

DOI: 10.1501/Tarimbil_0000001302

Corresponding Author: Mehmet BOZOGLU, E-mail: mehmetbo@omu.edu.tr, Tel: +90 (362) 31219 19/ 1371

Received: 10 February 2014, Received in Revised Form: 11 April 2014, Accepted: 21 April 2014

\begin{abstract}
About half of raw milk production in Turkey is sold under unsanitary conditions in open-air markets or by street vendors without following appropriate food safety standards and the consumers face a very high risk of consuming potentially unsafe dairy products. This research aims to assess consumers' awareness and attitudes about food safety, and to assess the market potential of certified labeled dairy products by determining consumers' purchase intention toward such products. The data was collected from a survey of 423 urban households by using the method of simple random sampling in Trabzon and Samsun provinces. In order to assess the market potential of certified labeled dairy products, an ordered probit model was specified and estimated to determine factors that may affect respondents' purchase decision. The study reveals that a vast majority of the respondents was not aware of food safety standards and they often purchased unsafe dairy products from farmers or open-air markets. The estimated model results show that factors such as food safety attribute, food poisoning experience, looking for food safety assurance, having information about food safety standards, college education and income have significant positive effects on consumers' purchase intention toward safety labeled dairy products, while concern for food poisoning has a significant negative effect.
\end{abstract}

Keywords: Food safety; Consumer awareness and behavior; Dairy products; Ordered probit, Turkey

\section{Karadeniz Bölgesi’ndeki Tüketicilerin Güvenilir Etiketli Süt Ürünlerini Satun Alma Niyetleri}

\section{ESER BILGISII}

Araştırma Makalesi

Sorumlu Yazar: Mehmet BOZOGLU, E-posta: mehmetbo@omu.edu.tr, Tel: +90 (362) 3121919 / 1371

Geliş Tarihi: 10 Şubat 2014, Düzeltmelerin Gelişi: 11 Nisan 2014, Kabul: 21 Nisan 2014

\section{ÖZET}

Türkiye'de üretilen sütün yaklaşık yarısı açık pazarlarda veya sokak satıcıları tarafından sağlıklı olmayan koşullarda satılmakta ve tüketiciler gıda güvenirliği olmayan süt ürünlerini tüketmelerinden dolayı potansiyel olarak yüksek bir risk 
ile karşı karşıya kalmaktadırlar. Bu araştırmada, tüketicilerin gıda güvenirliğine yönelik davranışları ve farkındalıkları ile gıda güvenirliği etiketli süt ürünlerine yönelik potansiyel satın alma niyetlerinin ortaya konulması amaçlanmıştır. Araştırmanın verileri, Samsun ve Trabzon illeri kent merkezlerindeki hanehalklarından basit tesadüfi örnekleme yöntemine göre seçilen 423 hanehalkı temsilcisiyle yapılan anketlerden elde edilmiştir. Tüketicilerin gıda güvenirliği etiketli süt ürünlerini satın alma kararlarına etkili faktörlerin tahmini ve pazar potansiyeli, sıralı probit modeliyle belirlenmiştir. Araştırma sonuçlarına göre, tüketicilerin büyük çoğunluğunun gıda güvenirliği standartlarından haberdar olmadıkları ve güvenirliği olmayan süt ürünlerini genellikle çiftçi veya açık pazarlardan temin ettikleri ortaya konulmuştur. Kurulan modelde ele alınan faktörlerden; gıda güvenirliği özelliği, olumsuz deneyim, gıda güvenirliği güvencesinin aranması, gıda güvenirliği standardından haberdar olma ile uygulanmasından duyulan memnuniyet, eğitim ve hanehalkı gelir düzeyi faktörlerinin güvenilir etiketli süt ürünleri satın alma niyetini istatistiki olarak olumlu yönde etkilediği, gıda zehirlenme riskinin ise olumsuz yönde etkilediği tespit edilmiştir.

Anahtar Kelimeler: Gıda güvenliği; Tüketici farkındalığı ve davranışı; Süt ürünleri; Sıralı probit, Türkiye

(C) Ankara Üniversitesi Ziraat Fakültesi

\section{Introduction}

Being healthy is a basic human need and right. Food is an important factor affecting human health. Because of its health effects, food safety standards should be applied by suppliers in both the production and processing stages. Food safety is considered to be the probability of not suffering certain hazards from consuming the food in question (Henson \& Traill 1993). Food safety is a universal concern, which can affect consumer market behavior and decisionmaking independently from other qualitative factors (Ritson \& Mai 1998). Consumers' demand for safer foods has increased significantly during the last two decades because of increasing income, population, education, urbanization, communication, and new technologies affecting people and the environment (Grunert 2005). Food safety standards are becoming important in the developing world as both a public health and trade policy issue. Officials in developing countries, mainly concerned with meeting the basic food needs of their populations until recent years, are now scrambling to put into place world-class food safety systems (Calvin et al 2006). Caswell \& Joseph (2006) argue that consumer demand for food safety, animal welfare, and environmental protection is expected to increase in the future and the issues will become major players and determinant factors in international markets.

Dairy products are an excellent source of nutrients. The recommended daily dairy products consumption is about $200-400 \mathrm{ml}$ for adults and $600-800 \mathrm{ml}$ for children and pregnant women (Miller et al 2000). Turkey produced 13.5 million tons of milk in 2010 and about one half of its volume (49.6\%) was sold under unsanitary conditions (e.g., in open-air markets) by farmers or street vendors without using appropriate handling standards to ensure the safety of the product. In 2011, the industry processed $41.2 \%, 23.2 \%, 16.2 \%, 13.5 \%$, and $5.9 \%$ of delivered milk into feta cheese, butter, milk, yoghurt and ayran (a cold yogurt beverage mixed with salt), respectively (TurkStat 2011). The dairy processing industry also suffered from lack of attention to food safety standards. Karaman (2012) stated that the majority of food safety problems occurred at the time of raw milk delivery, despite most dairy businesses implementing supplier safety criteria. Any microbiological, chemical, or physical contamination can affect a large group of the population and pose a considerable threat to public health.

While the food safety standards have been established in Turkey since the beginning of the 1990s, these standards have only been followed by the food processing industry since 2002. Instead of the Hazard Analysis Critical Control Point (HACCP) standard, the Turkish government has enforced the ISO 22000 standard since 2006 (WCS 2011). Domestic food safety standards, harmonized with international standards, have not been managed effectively. There have been numerous 
safety problems with dairy products. In 2007, the Ministry of Food, Agriculture, and Livestock (MFAL) reported that $65 \%$ of raw milk samples had higher than allowable amounts of total bacteria and somatic cells, $13.4 \%$ of 789 feta cheese samples had E. coli, while $4.4 \%$ and $0.08 \%$ of 794 feta cheese samples were contaminated with Staphylococcus aurous and Salmonella spp, respectively. The high level of contaminants found in dairy products is detrimental to the health and well-being of Turkish consumers and is of the utmost concern to public health officials and policymakers.

In Turkey, there have been many studies conducted about consumer behavior, preferences, and factors effecting the consumption of milk or dairy products (Hasipek \& Kaleli 2002; Hatirli et al 2004; Celik et al 2005; Akbay \& Tiryaki 2008; Kilic et al 2009; Ates \& Ceylan 2010; Tiryaki \& Akbay 2010; Seker et al 2012; Karakaya \& Akbay 2013). The food safety subject has also been studied in the farm, collection center and dairy industry sectors. For example, Armagan et al (2009) studied the knowledge, practice, and attitudes of dairy farmers on food safety. Other studies have focused on milk processing industry (Azabagaoglu \& Ince 2004), food safety practices and knowledge (Karaman 2012), and the constraints in meeting food safety requirements (Demirbas \& Karagozlu 2008; Karaman et al 2012) in dairy businesses at the local level in Turkey. However, consumers' purchase behavior regarding food safety in dairy products have not received much attention and not been addressed in depth. Thus, the main aim of this study is to assess consumer perception and awareness of food safety problems in dairy products (milk, yoghurt, feta cheese and butter) using the survey data collected in the Black Sea region of Turkey. Furthermore, this study determines the market potential and the likelihood that Turkish consumers would purchase safety labeled dairy products. Armed with the knowledge of what is lacking in consumers' awareness of food safety concepts, the policy makers will be able to design and implement effective programs to educate consumers regarding food safety issues. The identification of those important factors that may influence consumers' purchase intention will be helpful to the dairy industry in developing effective campaigns to promote the marketing of safety labeled dairy products.

In this paper, after the introduction section, the material and methods section concisely describes the survey design, the questionnaire and the ordered probit model used in the study. The main results obtained from the survey are presented and discussed in the results section and the last section contains conclusions.

\section{Material and Methods}

The research was conducted among the urban residents of Samsun and Trabzon provinces representing the Black Sea region of Turkey. By using a simple random sampling method, the adequate sample size was determined to be 423 households in two provinces. Only respondents responsible for the shopping within the household were selected and the sample respondents were recruited to participate in a face-to-face interview at various locations in markets, supermarkets, work places, and homes in October, 2011.

The questionnaire was designed to collect information about respondents' purchase behavior, food safety awareness, attitudes toward purchase of certified safe dairy products, and selected sociodemographic characteristics. Several questions regarding the frequency, quantity, and price paid for different dairy products (milk, yoghurt, feta cheese, and butter) at various markets were asked of the respondents to gain an understanding of their purchase pattern and behavior. The respondents were asked if they sometimes buy dairy products from farmers or local markets and about the importance of product attributes that may affect their purchase of each dairy product in question. To assess respondents' awareness and attitude toward food safety, the respondents were asked to rate the importance of various sources of possible food contamination ranging from microbial and chemical to technological hazards. With respect to purchase 
intention, the respondents were asked how likely if she or he would buy dairy products that are certified as being processed in compliance with the ISO 22000/HACCP standards. To facilitate the rating, a Likert scale of 1 to 5 was used with 1 being not at all important (or strongly disagree) to 5 being extremely important (or strongly agree). Information about negative personal experiences with any purchased dairy products and the respondents' perception, knowledge, and source of food safety information were also collected from the interviews.

Food safety is a major issue in public policy. Regulatory responses have fallen, roughly speaking, into two categories (Ritson \& Mai 1998). The first refers to the enforcement of common standards for food safety, which has no immediate impact on consumer food choice, but is debatable in terms of economic efficiency when consumer preferences for safety are assumed to be heterogeneous. The second refers to attempts to provide transparency and encourage consumers to form their own judgment on food safety, supported by mechanisms of public participation, consumer education, and consumer information instruments such as labeling (Grunert 2005). In Turkey, the use of ISO 22000 logo on the product package to identify the product meets the ISO safety standards is not mandatory and some firms do not use it. Although most respondents considered public institutions to be the top ranked agencies responsible for implementing and monitoring food safety standards, many of them believed that HACCP and ISO logos could be easily obtained from the certification agencies and would not necessarily guarantee the safety of dairy products due to the inadequate number of inspectors and the incidences of physical interference at the inspection sites.

In order to assess the market potential of certified safe or ISO labeled dairy products, an ordered probit was specified and estimated to determine factors that may affect respondents' purchase decision of certified safe dairy products. Specifically, let

$$
y^{*}=\beta^{\prime} \mathbf{x}+\varepsilon
$$

Where; $\beta$ is a vector of parameters to be estimated, and $\mathrm{x}$ is a matrix of independent variables. The dependent variable, $y^{*}$, in equation (1) is an unobserved latent variable. What is observed is

$$
\begin{aligned}
\mathrm{y} & =1 \text { if } \mathrm{y}^{*} \leq 0 \\
& =2 \text { if } 0<\mathrm{y}^{*} \leq \mu_{1}, \\
& ! \\
& =\mathrm{J} \text { if } \mu_{\mathrm{J}-1}<\mathrm{y}^{*},
\end{aligned}
$$

Where; y represents the outcome of choice category, and the $\mu s$ are unknown parameters to be estimated with $\beta$. Embedded in equations (1) and (2) is a threshold concept that choice outcome are generated by some explanatory variables that cross thresholds in the decision process. An individual responds to some exogenous stimuli with a certain choice when her/ his utility function or "degree of conviction" exceeds some threshold level. This threshold represented by the latent variable is unobservable, and only the outcome of the decision process is observed as presented in (2). Assuming $\varepsilon$ in (1) is normally distributed, the probabilities that a respondent will indicate the choice, the outcome categories are:

$$
\begin{aligned}
& \operatorname{Prob}(\mathrm{y}=1)=\Phi\left(-\beta^{\prime} \mathrm{x}\right), \\
& \operatorname{Prob}(\mathrm{y}=2)=\Phi\left(\mu 1-\beta^{\prime} \mathrm{x}\right)-\Phi\left(-\beta^{\prime} \mathrm{x}\right), \\
& ! \\
& \operatorname{Prob}(\mathrm{y}=\mathrm{J})=1-\Phi\left(\mu_{\mathrm{J}-1}-\beta^{\prime} \mathbf{x}\right) .
\end{aligned}
$$

To ensure all probabilities to be positive, it is necessary that $0<\mu_{1}<\mu_{2}<\mathrm{p}<\mu_{\mathrm{J}-1}$.In this study, the respondents' response to the questionnaire of how likely they would purchase dairy products that were certified to be safe and labeled with the ISO logo was classified into four categories, i.e., $y=1$ not at all likely or do not know; $y=2$ not very likely, neutral, or somewhat likely; $y=3$ very likely; and $y=4$ extremely likely.

\section{Results and Discussions}

\subsection{Consumers' characteristics and purchasing behavior}

The average respondent's age was 40.9 years and $73.3 \%$ of the respondents were females. The average household size was 3.6 persons and almost $87 \%$ of respondents were married. While $61.7 \%$ of the 
respondents had at most a high school education, more than one-third (36.9\%) of the respondents had an undergraduate or graduate degree. The education level of the respondents who purchased dairy products from markets or supermarkets was significantly higher than that of the respondents who purchased dairy products from farmers or open-air markets $(\mathrm{P}<0.01)$. In terms of the employment status, $37.8 \%, 29.1 \%$, and $26.7 \%$ of respondents were self-employed, home-maker and worked as a part or full-time employee, respectively. About $62 \%$ of the respondents owned their home. The $19.9 \%$ of household income was spent on food. The share of food expenditure was founded as $24 \%$ by Erdal \& Tokgoz (2011). Monthly income of the respondents who purchased dairy products from markets or supermarkets was significantly higher than that of the respondents who purchased from farmers or open-air markets $(\mathrm{P}<0.01)$. While $28.2 \%$ of the respondents purchased dairy products from only markets or supermarkets, the majority $(71.8 \%)$ purchased dairy products sometimes, often, or every time from farmers delivering to homes or at openair markets. About $54 \%$ of the respondents stated the main reason for purchasing milk from farmers or at open-air markets was to make yoghurt, butter, or rice pudding at home. The other stated reasons were: being additive free $(11.7 \%)$, better taste and purchasing habits $(11.4 \%)$, lower price $(9.3 \%)$, being fresher, clean, or healthy $(6 \%)$, home delivery $(3 \%)$, residing close to an open-air market (2\%), having confidence in farmers (1.3\%), and receiving free milk from parents $(0.3 \%)$. While $57.8 \%$ of milk, $57.5 \%$ of butter, $20.5 \%$ of yoghurt, and $16.6 \%$ of feta cheese were purchased from farmers or at open-air markets, the remaining respondents purchased their dairy products at markets or supermarkets. The shares of purchased milk from farmers or open-air markets were stated as very high (varied from 40.2 to 67.8 ) in the other researches (Celik et al 2005; Erdal \& Tokgoz 2011; Seker et al 2012). Planzer et al (2009) stated that in Brazil, 23.6\% of the respondents purchase feta cheese at an open-air market.

The inadequate hygiene at open-air markets is well known, especially due to the lack of temperature control, restrooms without proper hand-washing facilities, and protection against environmental contamination (Capistrano et al 2004). The survey reveals that about $31 \%$ of the respondents had a negative experience with dairy products such as early souring, bad taste and smell, molding, physical matter, and abnormal color. However, among those respondents who reported a bad experience, the vast majority of them $(74.6 \%)$ purchased dairy products from markets or supermarkets. Very few respondents had negative experiences purchasing dairy products from farmers. Only $0.5 \%$ and $0.7 \%$ of respondents experienced sickness symptoms such as vomiting, stomach pain, and diarrhea, fever resulting from consuming milk or feta cheese, respectively.

During the survey period, farmers in the research areas were selling milk for processing at $0.75 \mathrm{TL} \mathrm{lt}^{-1}$ in the research areas. The price could be doubled $\left(1.53 \mathrm{TL} \mathrm{t}^{-1}\right)$ if the farmers sold their milk at open-air markets or to consumers directly. The observed price difference is the primary motive behind farmers' direct sales to consumers or at open-air markets. Milk is considered fresher with home delivery. Akbay \& Tiryaki (2008) stated also that $49.08 \%$ of respondents thought that raw milk selling at open-air market is healthy. In addition, convenience of payment, better taste, and not being processed are some of the main reasons for buying milk directly from farmers or street sellers (Sayin 2011).

Table 1 shows that the average prices for milk at supermarkets and markets were $1.73 \mathrm{TL} \mathrm{L}^{-1}$ and 1.75 $\mathrm{TL} \mathrm{L}^{-1}$, respectively. Yoghurt prices purchased from different sellers vary from $1.42 \mathrm{TL} \mathrm{kg}^{-1}$ (farmers) to $2.25 \mathrm{TL} \mathrm{kg}^{-1}$ (markets). There were statistically significant differences in the dairy product prices among the purchase points $(\mathrm{P}<0.01$ to 0.10$)$. Similarly, consumers paid a much higher price for feta cheese and butter at markets or supermarkets than at open-air markets or from farmers directly. The average weekly consumption of milk, yoghurt, feta cheese, and butter was $4.49 \mathrm{lt}, 2.95 \mathrm{~kg}, 0.81 \mathrm{~kg}$, and $0.46 \mathrm{~kg}$, respectively. While the milk and butter consumption were significantly higher among the respondents who purchased from farmers or open-air markets, the yoghurt consumption was significantly higher among the respondents who purchased from markets or supermarkets $(\mathrm{P}<0.05)$. On average, 
Table 1- Milk products purchase by outlet type

Çizelge 1- Süt ürünlerinin satın alındığ yerler

\begin{tabular}{llcccc}
\hline & & \multicolumn{3}{c}{ Outlet type } \\
\cline { 3 - 6 } Products & \multicolumn{1}{c}{ Units } & Farmer & Open-air market & Market & Supermarket \\
\hline \multirow{3}{*}{ Milk } & Percentage (\%) & 38.06 & 19.39 & 45.63 & 24.35 \\
& Quantity (lt) & 4.5652 & 4.1524 & 2.1269 & 1.9806 \\
& Price (TL lt ${ }^{-1}$ ) & 1.5465 & 1.5160 & 1.7478 & 1.7294 \\
Yoghurt & Percentage (\%) & 4.73 & 8.98 & 37.35 & 16.78 \\
& Quantity (kg) & 0.1868 & 3.7632 & 2.6759 & 2.4930 \\
& Price (TL kg-1) & 1.4200 & 1.5321 & 2.2491 & 2.2320 \\
Feta cheese & Percentage (\%) & 3.31 & 13.24 & 55.56 & 28.37 \\
& Quantity (kg) & 4.2637 & 0.9464 & 0.9109 & 0.9958 \\
& Price (TL kg-1) & 8.6429 & 8.6161 & 9.7964 & 10.4696 \\
Butter & Percentage (\%) & 24.59 & 22.46 & 22.46 & 15.13 \\
& Quantity (kg) & 1.7168 & 1.0351 & 0.8784 & 0.9751 \\
\hline
\end{tabular}

the weekly expenditure for dairy products was 95.24 TL and its share in household income was $3.6 \%$. However, total dairy product expenditure was significantly higher among the respondents who purchased from markets or supermarkets $(\mathrm{P}<0.10)$.
According to survey respondents, freshness, taste and nutrition were considered to be the top three most important factors affecting purchase decisions of dairy products. As shown in Table 2, the food safety attribute apparently played a less

Table 2-The importance of dairy products attributes and possible food hazard sources

Çizelge 2- Süt ürünlerinin özelliklerinin önemi ve olası gıda risk kaynakları

\begin{tabular}{|c|c|c|c|c|c|c|}
\hline & (1) & (2) & (3) & (4) & (5) & Total score ${ }^{a}$ \\
\hline Product attributes & $\begin{array}{l}\text { Strongly } \\
\text { disagree }\end{array}$ & Disagree & $\begin{array}{c}\text { Neither agree } \\
\text { nor disagree }\end{array}$ & Agree & $\begin{array}{c}\text { Strongly } \\
\text { agree }\end{array}$ & \\
\hline Freshness & 0.24 & 0.71 & 0.00 & 22.22 & 76.83 & 474.45 \\
\hline Taste & 0.47 & 0.95 & 0.95 & 30.26 & 67.38 & 462.69 \\
\hline Nutritional ingredients & 12.19 & 10.64 & 5.20 & 33.81 & 38.06 & 362.42 \\
\hline Shelf-life & 0.00 & 2.36 & 1.65 & 28.37 & 67.61 & 461.20 \\
\hline Food safety & 0.47 & 1.18 & 3.07 & 34.75 & 60.52 & 453.17 \\
\hline Brand & 10.19 & 13.27 & 7.11 & 29.38 & 40.05 & 365.64 \\
\hline Package & 13.71 & 15.60 & 8.27 & 28.37 & 34.04 & 339.69 \\
\hline Color & 14.18 & 16.08 & 7.09 & 28.13 & 34.52 & 338.55 \\
\hline Prices & 16.78 & 16.55 & 4.49 & 27.42 & 34.75 & 330.00 \\
\hline Market location & 23.81 & 15.00 & 6.19 & 30.95 & 24.05 & 292.62 \\
\hline Organic product & 30.40 & 14.25 & 10.93 & 28.50 & 15.91 & 254.84 \\
\hline Possible hazard sources & $\begin{array}{l}\text { Not at all } \\
\text { important }\end{array}$ & $\begin{array}{l}\text { Somewhat } \\
\text { important }\end{array}$ & Important & $\begin{array}{c}\text { Very } \\
\text { important }\end{array}$ & $\begin{array}{l}\text { Extremely } \\
\text { important }\end{array}$ & \\
\hline Food poisoning & 0.00 & 0.47 & 4.26 & 24.11 & 71.16 & 465.96 \\
\hline Food spoilage & 0.00 & 0.47 & 7.80 & 29.31 & 62.41 & 453.63 \\
\hline Food additives & 0.71 & 9.24 & 25.12 & 28.20 & 36.73 & 391.00 \\
\hline Genetic modification & 5.21 & 11.14 & 20.38 & 26.78 & 36.49 & 378.20 \\
\hline Hormones & 7.33 & 14.89 & 19.62 & 28.61 & 29.55 & 358.16 \\
\hline Fertilizers & 5.91 & 17.97 & 21.75 & 28.61 & 25.77 & 350.39 \\
\hline Pesticides\&herbicides & 7.33 & 20.57 & 22.22 & 23.88 & 26.00 & 340.65 \\
\hline Veterinary medicines & 20.14 & 23.22 & 18.96 & 21.09 & 16.59 & 290.77 \\
\hline
\end{tabular}

a, total score was computed as the sum of all respondents' answers to each question about possible hazard source; the score ranged from 1 (not at all important) to 5 (extremely important) 
prominent role in respondents' purchasing decisions. Similar results regarding the importance of safety attributes in dairy products was reported by Wang et al (2008). Other important product attributes that may affect respondents' purchase decisions were brand, nutritional ingredients, package, color, price, market location, and being organic. Those respondents who purchased dairy products from farmers or open-air markets gave lesser importance to product attributes such as nutritional ingredients, food safety, color, prices, and total attributes than that of the respondents purchasing from markets or supermarkets $(\mathrm{P}<0.01$ to 0.05$)$. It is interesting to note that organic products or being organic was considered the least important attribute among the surveyed respondents.

\subsection{Risk awareness, perceptions and attitudes on food safety}

Perceptions and attitudes can influence the decisionmaking process and buying behavior of each individual. Perceptions represent the formation of an individual state of mental awareness that is affected by internal and external environmental stimuli such as economic, social, and cultural influences (Radam et al 2010). The survey results suggest that the respondents considered food poisoning, spoilage, and additives as the most important hazards to dairy products (Table 2). While genetic modification and use of growth hormone were stated as moderate hazard sources, chemical fertilizers, pesticides and herbicides, and veterinary medications were perceived as less important hazard sources. Brewer \& Rojas (2008) noted that the chemicals used in production are poorly understood by consumers, which may have potentially dangerous or known longterm effects over which consumers have little control.

The role of information is crucial in evaluating attention to food safety (Wang et al 2009). Although the majority of the respondents $(83.5 \%)$ indicated that they knew the meaning of food safety, $53.4 \%$ of them had not heard about the ISO 22000 standards before. The respondents who purchased dairy products from markets or supermarkets had significantly higher awareness about the food safety standards than the respondents who purchased from farmers or open-air markets $(\mathrm{P}<0.01)$. While most respondents obtained their food safety information from the mass media, a university or workplace also served as important information sources to learn about food safety standards. Our results appear consistent with Buzby et al (1995) who reported newspaper articles as the main information source about food safety.

Only $21.7 \%$ of respondents either often or occasionally looked for the ISO 22000 logo on product packages when shopping for dairy products. The main reasons cited for not looking for the ISO 22000 logo were the lack of information about the ISO 22000 standards; relying on the brand; not used to or forgot to look for the logo; not trusting ISO standards; and reliance on the MFAL. There is an apparent trust issue regarding the current food safety standards on dairy products. Many respondents thought that insufficient attention was given to human health because the responsible government agencies have not done a good job in implementing and monitoring appropriate food safety standards. The survey suggests that about $30 \%$ of the respondents thought that the standards had not been monitored effectively and only slightly more $20 \%$ of respondents were at least somewhat satisfied with the implemented food safety standards. The respondents who purchased dairy products from markets or supermarkets had significantly higher satisfaction regarding the implementation of food safety standards than the respondents who purchased from farmers or open-air markets $(\mathrm{P}<0.01)$.

\subsection{Purchase intention on ISO labeled dairy products}

Table 3 presents the definitions and sample statistics of the variables included in the estimation of the ordered probit model. As shown in Table 3, the vast majority of respondents indicated that they either don't know or not at all likely to buy ISO labeled dairy products. If this is true, then the market potential for promoting ISO labeled safer dairy products could be questionable. In assessing the market potentials, market planners, product developers, and policy makers need to understand what important factors that affect the respondents' purchase intention. In this case, the application of the ordered probit model is particularly attractive from the standpoint of market research. 
Table 3-Variables definitions and sample characteristics

Çizelge 3- Değişkenlerin tanımları ve örnek özellikleri

\begin{tabular}{|c|c|c|c|}
\hline Variable & Definition & Mean & Std. dev. \\
\hline $\mathrm{y}$ & $\begin{array}{l}\text { Categorical dependent variable, }=1 \text { if not at all likely or don't know } \\
(59.34 \%) ;=2 \text { if not very likely, neutral, or somewhat likely }(21.04 \%) \text {; } \\
=3 \text { if very likely }(14.42 \%) \text {; and }=4 \text { if extremely likely }(5.20 \%) \text { to buy } \\
\text { ISO labeled dairy products }\end{array}$ & 1.6548 & 0.9102 \\
\hline Samsun & $=1$ if the resides in Samsun province; 0 otherwise & 0.6879 & 0.4639 \\
\hline Supermkt & $\begin{array}{l}=1 \text { if the respondent buys their dairy products mostly from super- } \\
\text { market; } 0 \text { otherwise }\end{array}$ & 0.1962 & 0.3976 \\
\hline Freshness & $\begin{array}{l}=1 \text { if freshness is considered an important product attribute; } 0 \text { oth- } \\
\text { erwise }\end{array}$ & 0.9905 & 0.0969 \\
\hline Price & $=1$ if price is considered an important product attribute; 0 otherwise & 0.6217 & 0.4856 \\
\hline Safety & $\begin{array}{l}=1 \text { if food safety is considered an important product attribute; } 0 \\
\text { otherwise }\end{array}$ & 0.9527 & 0.2125 \\
\hline Concern_poi & $\begin{array}{l}=1 \text { if food poisoning is an important concern of food hazard source; } \\
0 \text { otherwise }\end{array}$ & 0.9953 & 0.0687 \\
\hline Badexp & $\begin{array}{l}=1 \text { if the respondent has any bad experience with dairy products dur- } \\
\text { ing the last } 12 \text { months; } 0 \text { otherwise }\end{array}$ & 0.3097 & 0.4629 \\
\hline Know & $=1$ if the respondent knows the meaning of food safety; 0 otherwise & 0.8351 & 0.3804 \\
\hline Look_ISO & $\begin{array}{l}=1 \text { if the respondent often looks for food safety assurance while } \\
\text { shopping; } 0 \text { otherwise }\end{array}$ & 0.2175 & 0.4130 \\
\hline Aware_ISO & $\begin{array}{l}=1 \text { if the respondent has heard any information about food safety } \\
\text { standards (ISO 22000/HACCP); } 0 \text { otherwise }\end{array}$ & 0.4657 & 0.4994 \\
\hline Satisfy & $\begin{array}{l}=1 \text { if the respondent is at least somewhat satisfied with food safety } \\
\text { standards (ISO } 22000 / \mathrm{HACCP} \text { ) on dairy products; } 0 \text { otherwise }\end{array}$ & 0.2033 & 0.4029 \\
\hline Owner & $=1$ if the respondent owns his/her home; 0 otherwise & 0.6217 & 0.4855 \\
\hline Age_19-34 & $\begin{array}{l}=1 \text { if the age of the respondent is between } 19 \text { and } 34 \text { years; } 0 \text { other- } \\
\text { wise }\end{array}$ & 0.3097 & 0.4629 \\
\hline Child & $=1$ if there is a child presence in the household; 0 otherwise & 0.2175 & 0.4130 \\
\hline Edu_hs & $=1$ if the respondent has a high school education; 0 otherwise & 0.2530 & 0.4352 \\
\hline Edu_co & $=1$ if the respondent has at least a college degree; 0 otherwise & 0.3688 & 0.4830 \\
\hline Employed & $=1$ if the respondent has an employment; 0 otherwise & 0.6478 & 0.4782 \\
\hline Hsize & Household size in number of persons & 3.5508 & 1.1340 \\
\hline Income & Monthly family income (TL) & $2,643.16$ & $1,595.84$ \\
\hline
\end{tabular}

The estimation results are presented in Table 4, which shows that the model fits the data reasonably well with a 0.34 pseudo $\mathrm{R}^{2}$, which is considered a good fit for qualitative model based on survey data. In addition, the $\chi^{2}$ likelihood ratio test also indicates that the fitted model is highly significantly different from the restricted model at the less than 0.0001 significance level. Most variables related to awareness and concerns about food safety standards are found to be statistically significant at less than the 0.10 significance level as to be expected. However, college education and household income are the only 
Table 4- Estimation results of the ordered probit model

Çizelge 4- Stralı probit modelinin tahmin sonuçları

\begin{tabular}{|c|c|c|c|c|}
\hline Variable & Coefficient & Stand error & $z$ & $P>z$ \\
\hline Samsun & $0.5405^{* * *}$ & 0.1726 & 3.13 & 0.002 \\
\hline Supermkt & -0.0612 & 0.1658 & -0.37 & 0.712 \\
\hline Freshness & -0.103 & 0.6313 & -0.16 & 0.870 \\
\hline Price & 0.2264 & 0.1481 & 1.53 & 0.126 \\
\hline Safety & $1.3513^{* *}$ & 0.6505 & 2.08 & 0.038 \\
\hline Concern poi & $-2.9321^{* * *}$ & 1.0700 & -2.74 & 0.006 \\
\hline Badexp & $0.2915^{* *}$ & 0.1403 & 2.08 & 0.038 \\
\hline Know & 0.3487 & 0.2209 & -1.58 & 0.115 \\
\hline Look ISO & $0.6670^{* * *}$ & 0.1696 & 3.93 & 0.000 \\
\hline Aware ISO & $1.2105^{* * *}$ & 0.1798 & 6.73 & 0.000 \\
\hline Satisfy & $0.4984^{* * *}$ & 0.1669 & 2.99 & 0.003 \\
\hline Owner & -0.0465 & 0.1439 & -0.32 & 0.747 \\
\hline Age 19-34 & 0.1905 & 0.1601 & 1.19 & 0.234 \\
\hline Child & -0.2174 & 0.1802 & -1.21 & 0.228 \\
\hline Edu hs & 0.2412 & 0.2081 & 1.16 & 0.246 \\
\hline Edu_co & $0.4328^{* *}$ & 0.2175 & 1.99 & 0.047 \\
\hline Employed & 0.2621 & 0.1771 & 1.48 & 0.139 \\
\hline Hsize & -0.0541 & 0.0673 & -0.8 & 0.422 \\
\hline Income & $0.0001^{* *}$ & $4.97 \mathrm{E}-05$ & 2.08 & 0.038 \\
\hline$\mu_{1}$ & 0.4837 & 1.1278 & & \\
\hline$\mu_{2}$ & 1.5922 & 1.1307 & & \\
\hline$\mu_{3}$ & 2.7046 & 1.1412 & & \\
\hline Log likelihood & -299.4891 & & & \\
\hline Likelihood Ratio $\chi^{2}$ & 306.81 & & & \\
\hline Pseudo $\mathrm{R}^{2}$ & 0.3387 & & & \\
\hline Sample size & 423 & & & \\
\hline
\end{tabular}

two socio-economic variables that have significant positive effects on purchase intention toward ISO labeled safe dairy products. The estimated coefficients presented in Table 4 are not very meaningful for interpretation by themselves. They only provide an indication on how the choice outcome will change if the explanatory variable is to change by one unit. Thus, a positive coefficient indicates that a one unit increase of the explanatory variable would cause the choice response to move to a higher category. For example, the results suggest that respondents from Samsun province are more likely to purchase dairy products that are labeled with ISO 22000 logo than those residing in Trabzon province. Similarly, those respondents who consider food safety as an important product attributes are more likely to buy dairy products that are certified safe and so labeled than their counterparts. However, the estimated coefficient says nothing about the intensity of purchase intention. To gain more insights from the estimation results, it is useful to examine the marginal effects or the marginal probabilities associated with each explanatory variable included in the model.

The estimated marginal probabilities are presented in Table 5. It is noted that the marginal effects measure the changes in probabilities of purchase intention among the categories due to a unit change of the explanatory variable. Thus, the sum of marginal probabilities among all categories in a row is equal to zero. In other words, the gains and losses in marginal probabilities among all categories will balance out as the probabilities add to 1 . As shown in Table 5, those respondents who have heard information or have some awareness of ISO 22000/HACCP safety standards are most likely to buy safety labeled dairy products with a largest shift of $42.7 \%$ probabilities out of "not at all likely" $(y=1)$ category. The shift in probabilities occurs mostly to "not very likely to somewhat likely" $(y=2)$ and they are highly statistically 
Table 5- Estimated marginal probabilities of the ordered probit model

Çizelge 5-Stralı probit modelinin tahmin edilmiş marjinal olasılıkları

\begin{tabular}{|c|c|c|c|c|}
\hline \multirow[b]{2}{*}{ Variable } & \multicolumn{4}{|c|}{ Category } \\
\hline & $Y=1$ & $Y=2$ & $Y=3$ & $Y=4$ \\
\hline Samsun & $-0.186^{* * * *}$ & $0.128^{* * * *}$ & $0.053^{* * *}$ & $0.005^{\text {** }}$ \\
\hline Supermkt & 0.022 & -0.015 & -0.007 & -0.001 \\
\hline Freshness & 0.038 & -0.025 & -0.012 & -0.001 \\
\hline Price & -0.081 & 0.055 & 0.024 & 0.003 \\
\hline Safety & $-0.316^{* * *}$ & $0.248^{* * *}$ & $0.064^{* * *}$ & $0.005^{* *}$ \\
\hline Concern poi & $0.662^{* * *}$ & 0.194 & -0.252 & -0.604 \\
\hline Badexp & $-0.108^{* *}$ & $0.069^{* *}$ & $0.035^{*}$ & 0.004 \\
\hline Know & $-0.120^{*}$ & 0.084 & $0.033^{*}$ & $0.003^{*}$ \\
\hline Look ISO & $-0.254^{* * *}$ & $0.145^{* * *}$ & $0.095^{* * *}$ & $0.014^{* *}$ \\
\hline Aware ISO & $-0.427^{* * * *}$ & $0.257^{* * *}$ & $0.148^{* * *}$ & $0.022^{* * *}$ \\
\hline Satisfy & $-0.190^{* * * *}$ & $0.113^{* * *}$ & $0.068^{* *}$ & $0.009^{*}$ \\
\hline Owner & 0.017 & -0.011 & -0.005 & -0.001 \\
\hline Age 19-34 & -0.070 & 0.046 & 0.022 & 0.003 \\
\hline Child & 0.077 & -0.053 & -0.022 & -0.002 \\
\hline Edu hs & -0.090 & 0.057 & 0.029 & 0.003 \\
\hline Edu co & $-0.160^{* *}$ & $0.102^{* *}$ & $0.052^{*}$ & 0.006 \\
\hline Employed & -0.094 & 0.063 & 0.028 & 0.003 \\
\hline Hsize & 0.020 & -0.013 & -0.006 & -0.001 \\
\hline Income & $-3.8 \mathrm{E}-05^{* *}$ & $2.49 \mathrm{E}-05^{* *}$ & $1.15 \mathrm{E}-05^{* *}$ & $1.25 \mathrm{E}-06^{*}$ \\
\hline
\end{tabular}

significant at less than the 0.01 significance level. The "very likely" ( $y=3)$ group increases the probability of purchase intention by $14.8 \%$. On the other hand, those respondents who considered food poisoning an important source of food hazard are most unlikely to purchase dairy products with ISO logo. This finding appears counter intuitive. A possible explanation could be traced back to the trust issue that most people do not believe the ISO label could sufficiently guarantee the safety of dairy product from food poisoning. Nevertheless, many marketing implications could be drawn from the estimated results. Higher education attainment and income level are two important factors that would motivate consumer to buy safety labeled dairy products. It is evident that to effectively promote the market potential of safety labeled dairy products, product developer and policy makers should focus on educating the consumers about the importance of ISO 22000/HACCP safety standards. The safety standards need to be strictly and effectively enforced to gain consumers' confidence and trust in food safety labels.

\section{Conclusions}

About half of Turkey's raw milk production is marketed unprocessed or under unsafe conditions by street vendors. Empirical studies of consumer perceptions and awareness of food safety issues provide critical information to public officials for designing appropriate food safety regulations and to commercial interests in devising food marketing strategies for emerging markets (Wang et al 2008). Enhancing food safety regulations in Turkey's dairy sector could protect public health and increase social welfare. In this study, we analyzed consumers' perceptions and awareness about food safety and estimated the likelihood of their purchase intention toward dairy products that are certified and labeled in compliance with ISO 22000/HACCP standards.

An important finding of this study is that the majority of respondents $(70 \%)$ purchased more than one half of consumed milk and butter and about one-fourth of yoghurt and feta cheese directly from farmers or at open-air markets. This means that the respondents faced a very high risk of consuming potentially unsafe dairy products. Those consumers 
who are accustomed to the open-air markets or buying dairy products directly from farmers should be educated and persuaded to change their habits by shopping at the markets or supermarkets, where safer dairy products are offered. As the study reveals, most surveyed Turkish consumers rated freshness and taste being more important than safety concerns. This attitude seems to account for the underlying reasons for their preference of purchasing dairy products directly from farmers or at open-air markets. Thus, in order to be competitive, the dairy industry should focus on quality improvements as well as innovative marketing strategies to convince consumers that their dairy products are not only safer, but also just as fresh and good tasting when purchased from supermarkets. On the other hand, the government can enforce stricter regulations to discourage the sale of dairy products at open-markets or directly to consumers. In addition, dairy farmers should be encouraged to organize farm cooperatives for processing their milk, so they can realize a higher price for raw milk than the processing industry has to offer. The expansion of the agricultural cooperative sector in processing farmer-member milk could help transform the current marketing channels and reduce farmers' incentives to sell milk at open-air markets or directly to consumers.

In this study, we found also that a vast majority of respondents was unaware of food safety standards and the number of those dissatisfied with the implementation of the standards is alarming and serves as a warning sign to public health officials. The lack of trust and satisfaction about government's implementation and monitoring of food safety standards could be seen as a major barrier in promoting the purchase of safety labeled dairy products. The results suggest that there is an urgent need for the Turkish government to educate consumers about important measures to ensure their foods are safe to eat and to provide adequate controls to guarantee the safety of the nation's food supply. The government should design and establish its educational campaigns to promote awareness and clarify the hazards and risks coming from consuming non-inspected dairy products, and inform people on how to check and understand food safety information.
Further research is needed to advance the understanding of differences in responses among population segments to information about food safety. Similar research to include both urban and rural areas in other regions and at the country level could be helpful in generalizing food policy implications obtained from this study. Furthermore, extending research into other dairy products such as kosher cheese, curd cheeses, dry milk, and buttermilk would be highly desirable. There is also a need to investigate the supply side of food safety in terms of the costs of implementation to both dairy farms and the milk processing industry.

\section{Acknowledgements}

This research was conducted while the first authors were a postdoctoral fellow at the Department of Agricultural and Applied Economics, the University of Georgia (USA) during 2011-2012. The work was supported the Scientific and Technological Council of Turkey (the program of 2219) and Ondokuz Mayis University (the program of 1922). We would like to thank Şahinde Sili, Nur İlkay Sonmez and Nevra Alhas Eroğlu for conducting the questionnaires and two anonymous referees for useful comments.

\section{References}

Akbay C \& Tiryaki G Y (2008). Unpacked and packed fluid milk consumption patterns and preferences in Turkey. Agricultural Economics 38: 9-20

Armagan G, Koc A \& Ozden A (2009). Food safety at the dairy farm level: knowledge, practices and attitudes of farmers. Milchwissenschaft 64(1): 6-9

Ates H C \& Ceylan M (2010). Effects of socio-economic factors on the consumption of milk, yoghurt, and cheese: insights from Turkey. British Food Journal 112(3): 23-250

Azabagaoglu M O \& Ince F (2004). Kırklareli İlınde süt sanayinin durumu. Tartm Bilimleri Dergisi-Journal of Agricultural Sciences 10(3): 323-328

Brewer MS \& Rojas M (2008). Consumer attitudes toward issues in food safety. Journal of Food Safety 28: 1-22

Buzby J C, Ready R C \& Skees J R (1995). Contingent valuation in food policy analysis: a case study of a pesticide-residue risk reduction. Journal of Agricultural and Applied Economics 27(2): 613-625 
Calvin L, Gale F, Hu D \& Lohmar B (2006).Food safety improvements underway in China. Amber Waves 4(5): $16-21$

Capistrano D I, Germano P M I \& Germano M I S (2004). Open-air markets in Sao Paulo city: Hygienicsanitary. Hi Aliment 18: 37-42

Caswell J A \& Joseph S (2006). Consumers' food safety, environmental and animal welfare concerns: Major determinants for agricultural and food trade in the future? In. IATR Symposium of Food Regulation and Trade: Institutional Framework, Concepts of Analysis and Empirical Evidence, May 28-30, Bonn, Germany

Celik Y, Karli B, Bilgic A \& Celik S (2005). The level of milk consumption and consumption pattern of consumers in Sanliurfa urban areas. Tarim Ekonomisi Dergisi 11(1): 5-12

Demirbas N \& Karagozlu C (2008). Constraints in meeting food safety and quality requirements in the Turkish dairy industry: a case study of Izmir Province. Journal of Food Protection 3: 76-80

Erdal G \&Tokgoz K (2011). Factors affecting preferences of packed and unpacked milk consumption of consumers: A case study of Erzincan. KMÜ Sosyal ve Ekonomik AraştırmalarDergisi 13(20): 111-115

Grunert KG (2005). Food quality and safety: Consumer perception and demand. European Review of Agricultural Economics 32(3): 369-391

Hasipek S \& Kaleli N (2002). Ankara Üniversitesi Ziraat Fakültesinin yurtta kalan kız ve erkek öğrencilerinin süt ve süt ürünleri tüketim sıklığ1 üzerinde bir araştırma. Journal of Agricultural Sciences 8(3): 204-207

Hatirli S A, Ozkan B \& Aktas A R (2004). Factors affecting fluid milk purchasing sources in Turkey. Food Quality and Preference 15: 509-515

Henson S \& Traill B (1993). The demand for food safety: Market imperfections and the role of government. Food Policy 18(2): 152-162

Karakaya E \& Akbay C (2013). Consumer consumption habits of milk and milk products in Istanbul province. Journal of Agricultural Faculty of Uludag University 27(1): $65-77$

Karaman A D (2012).Food safety practices and knowledge among Turkish dairy businesses in different capacities. Food Control 26: 125-132

Karaman A D, Cobanoglu F, Tunalioglu R \& Ova G (2012). Barriers and benefits of the implementation of food safety management systems among the Turkish dairy industry: A case study. Food Control 25: 732739

Kilic O, Akbay C \& Tiryaki G Y (2009). Factors affecting packed and unpacked fluid milk Consumption. Agricultural Economics -Czech 55(11): 557-563

Miller G D, Jarvis K J, McBean L D (2000). Handbook of dairy foods and nutrition. In: R G Jensen \&M Kroger (Eds), The Importance of Milk and Milk Products in the Diet. CRC Press, New York, pp. 4-24

Planzer S B, Cruz A G, Sant'ana A S, Silva R, Moura M R L \& De Carvalho L M J (2009). Food safety knowledge of cheese consumers. Journal of Food Science 74(1): 28-30

Radam A, Yacob M R, Bee T S \& Selamat J (2010). Consumers' perceptions, attitudes and willingness to pay towards food products with "no added msg" labeling. International Journal of Marketing Studies 2(1): 65-77

Ritson C \& Mai L W(1998). The economics of food safety. Nutrition and Food Science 98: 253-259

Sayin C (2011). The evaluation of the point of views of the producers who supply raw milk to milk rounds men: Antalya province case. Anadolu Journal of Agricultural Sciences 26(2): 149-155

Seker I, Seker P, sahin M, Ozen V S, Akdeniz A, Erkmen O, Kislali I, Sargın G \& Dogu G B (2012). Elazı̆̆ ili merkez ilçede tüketicilerin süt tüketim alışkanlıkları ve bu alışkanlıkları etkileyen faktörlerin belirlenmesi. Fırat Üniversitesi Sağlık Bilimeleri Veteriner Dergisi 26(3): 131-143

Tiryaki G Y \& Akbay C (2010). Consumers' fluid milk consumption behaviors in Turkey: an application of multinominallogit model. Qual Quant 44: 87-98

TurkStat (2011). Milk Products Production Statistics. Turkish Statistical Institute News Bulletin, Number 30, Ankara. http://turkstat.gov.tr (Accessed 01.11.2012)

Wang Z, Mao Y \& Gale F (2008). Chinese consumer demand for food safety attributes in milk products. Food Policy 33: 27-36

Wang F, Zhang J, Mu W, Fu Z \& Zhang X (2009). Consumers' perception toward quality and safety of fishery products, Beijing, China. Food Control 20: 918-922

WCS (2011). ISO 22000 HACCP Tarihsel Gelişim. www.wcs.com.tr/iso22000_tarihsel_htm (Accessed 2011.10.02) 